\title{
Evaluation of Macroalgae Sulfated Polysaccharides on the Leishmania (L.) amazonensis Promastigote
}

\author{
Camila Lehnhardt Pires ${ }^{1, *}$, Selma Dzimidas Rodrigues ${ }^{1}$, Daniel Bristot ${ }^{1}$, \\ Henrique Hessel Gaeta ${ }^{1}$, Daniela de Oliveira Toyama ${ }^{2}$, Wladimir Ronald Lobo Farias ${ }^{3}$ \\ and Marcos Hikari Toyama ${ }^{1}$
}

1 São Vicente Unit, State University of São Paulo Julio Mesquita Filho, UNESP, Praça Infante Dom Henrique, s/n, São Vicente 11330-900, SP, Brazil; E-Mails: sdr1@clp.unesp.br (S.D.R.); dbristot@hotmail.com (D.B.); henriquehg@gmail.com (H.H.G.); mhtjpn@gmail.com (M.H.T.) Center of Biological and Health Sciences, Mackenzie Presbyterian University, Rua da Consolação, 896, São Paulo 01302-907, SP, Brazil; E-Mail: gaveira@yahoo.com.br

3 Pici Unit, Federal University of Ceará, UFC, Av. Mister Hull, s/n, Bloco 827, Fortaleza, CE, 60356-000, Brazil; E-Mail: wladimir@ufc.br

* Author to whom correspondence should be addressed; E-Mail: lehnhardtpires@gmail.com; Tel.: +55-13-8809-7200; Fax: +55-13-3569-7106.

Received: 17 January 2013; in revised form: 28 January 2013 / Accepted: 25 February 2013 / Published: 20 March 2013

\begin{abstract}
The sulfated polysaccharides from Solieria filiformis (Sf), Botryocladia occidentalis (Bo), Caulerpa racemosa $(\mathrm{Cr})$ and Gracilaria caudata $(\mathrm{Gc})$ were extracted and extensively purified. These compounds were then subjected to in vitro assays to evaluate the inhibition of these polysaccharides on the growth of Leishmania (L.) amazonensis promastigotes. Under the same assay conditions, only three of the four sulfated polysaccharides were active against L. amazonensis, and the polysaccharide purified from $\mathrm{Cr}$ was the most potent $\left(\mathrm{EC}_{50}\right.$ value: $\left.34.5 \mu \mathrm{g} / \mathrm{mL}\right)$. The polysaccharides derived from $\mathrm{Bo}$ and $\mathrm{Sf}$ demonstrated moderate anti-leishmanial activity $\left(\mathrm{EC}_{50}\right.$ values of $63.7 \mu \mathrm{g} / \mathrm{mL}$ and $137.4 \mu \mathrm{g} / \mathrm{mL}$ ). In addition, we also performed in vitro cytotoxic assays toward peritoneal macrophages and $\mathrm{J} 774$ macrophages. For the in vitro cytotoxicity assay employing $\mathrm{J} 774$ cells, all of the sulfated polysaccharides decreased cell survival, with $\mathrm{CC}_{50}$ values of $27.3 \mu \mathrm{g} / \mathrm{mL}, 49.3 \mu \mathrm{g} / \mathrm{mL}, 73.2 \mu \mathrm{g} / \mathrm{mL}$, and $99.8 \mu \mathrm{g} / \mathrm{mL}$ for Bo, Cr, Gc, and Sf, respectively. However, none of the sulfated polysaccharides reduced the cell growth rate of the peritoneal macrophages. These results suggest that macroalgae contain compounds with various chemical properties that can control specific pathogens. According to our results, the assayed sulfated polysaccharides were able to modulate the growth rate and cell
\end{abstract}


survival of Leishmania (L.) amazonensis promastigotes in in vitro assays, and these effects involved the interaction of the sulfated polysaccharides on the cell membrane of the parasites.

Keywords: macroalgae; Leishmania (L.) amazonensis; sulfated polysaccharides; Solieria filiformis; Botryocladia occidentalis; Caulerpa racemosa; Gracilaria caudate

\section{Introduction}

The surface of protozoan parasites, such as those belonging to the parasite genus Leishmania, is responsible for regulating interactions with the extracellular environment and is involved in the absorption of nutrients and signaling pathways. According to Azevedo-Pereira et al. [1], there is evidence that heparin-binding proteins (HBPs) present on the surface of Leishmania spp. may play important roles in the life cycle of parasites and in defining the success of parasite attachment to and invasion of tissues of the mammalian and invertebrate hosts. In addition, there is evidence that HBPs can promote internalization and signaling in the host cells during the infection time course. More recently, de Castro Côrtes et al. [2] isolated metallo-protease protein fractions from the flagella or membrane promastigotes of $L$. $(V)$ braziliensis that were capable of forming stable complexes with glycosaminoglycans (heparin-like activity). Additionally, de Castro Côrtes et al. [3] showed that these HBPs modulate the activity of signaling in the cellular environment and play specific roles in the host-parasite interactions of Leishmania $(V$.) braziliensis.

Although heparin is not found on the surface of host cells, this glycosaminoglycan (GAG) has been commonly used as a tool for studying pathogen-host cell interactions. It was previously demonstrated that amastigotes of $L$. (L.) amazonensis and Leishmanai (L.) major have a greater ability to bind to heparin than promastigotes of these same species. In addition, GAGs, including heparin, can induce the proliferation of $L$. (L.) major in the gut of the insect vector, increasing the load of experimentally infected insects. There is evidence that the HBPs present on the surface of Leishmania spp. can play an important role in the life cycle of parasites, defining the success of parasite binding and invasion of the host tissues of mammals and invertebrates. In the parasite species in which these proteins were identified, the HBPs act as adhesion proteins and can promote internalization and signaling in host cells [2].

Marine macroalgae have high concentrations of sulfated polysaccharides (SP), heterogeneous and complex macromolecules with significant importance to the physiology of algae. These compounds have been explored in the biomedical field, indicating the therapeutic potential of sulfated polysaccharides [4]. In this respect, extracts produced from green, brown, and red algae have already demonstrated significant activity against fungi, bacteria, viruses and protozoa [5,6]. However, until now, few works have demonstrated the anti-leishmanial activity of seaweed extracts. Recently, results have shown that the selective index of extracts is very high in different experimental models, suggesting low toxicity of algae extracts to mammalian cells, which in turn can be explored to develop new candidate drugs against diseases and to examine different pathological conditions. In this study, we evaluated the effects of four highly purified sulfated polysaccharides from Solieria filiformis (Sf), 
Botryocladia occidentalis (Bo), Caulerpa racemosa $(\mathrm{Cr})$ and Gracilaria caudate $(\mathrm{Gc})$ on the growth of Leishmania (L.) amazonensis promastigote, as well as their cytotoxic effects.

\section{Results and Discussion}

The sulfated polysaccharides used in this study were extensively purified from the crude extracts of Solieria filiformis (Sf), Botryocladia occidentalis (Bo), Caulerpa racemosa (Cr) and Gracilaria caudate $(\mathrm{Gc})$ by Diethylamionoethyl (DEAE) ion exchange chromatography. These fractions were then subjected to a new chromatography process using a TSKgel G3000SW column with a molecular size exclusion stationary phase previously equilibrated with phosphate buffer. The size exclusion chromatographic analyses of the sulfated polysaccharides (SP) fractions from the DEAE column of Gc, Sf, Bo and $\mathrm{Cr}$ showed several fractions, including one main peak that corresponded to approximately $35 \%$ of the whole fraction (Figure 1). The molecular mass of $\mathrm{Gc}, \mathrm{Sf}, \mathrm{Bo}$ and $\mathrm{Cr}$ were estimated to be greater than $200 \mathrm{kDa}, 30 \mathrm{kDa}$ and $25 \mathrm{kDa}$, respectively, according to the molecular mass markers: blue dextran $(2000 \mathrm{kDa}) ; \beta$-amylase $(225 \mathrm{kDa})$; and bovine serum albumin (BSA, Sigma, $66 \mathrm{kDa}$ ), which forms a natural dimer of $120 \mathrm{kDa}$; ovalbumin (OVA, $43 \mathrm{kDa}$ ); carbonic anhydrase (CA, $29 \mathrm{kDa})$; and ribonuclease (RA, $14 \mathrm{kDa})$.

Figure 1. Chromatographic profile of the size exclusion fractionation of sulfated polysaccharides in TSKgel G3000SW silica-based GFC columns. Samples of $1 \mathrm{mg} / \mathrm{mL}$ were dissolved in phosphate buffer and centrifuged at $4500 \times \mathrm{g}$ for $5 \mathrm{~min}$, and the supernatant was applied to the column. The flow rate was maintained at $1 \mathrm{~mL} / \mathrm{min}$, and the eluent was monitored by fluorescence. The purified fractions of the sulfated polysaccharides were named SP.

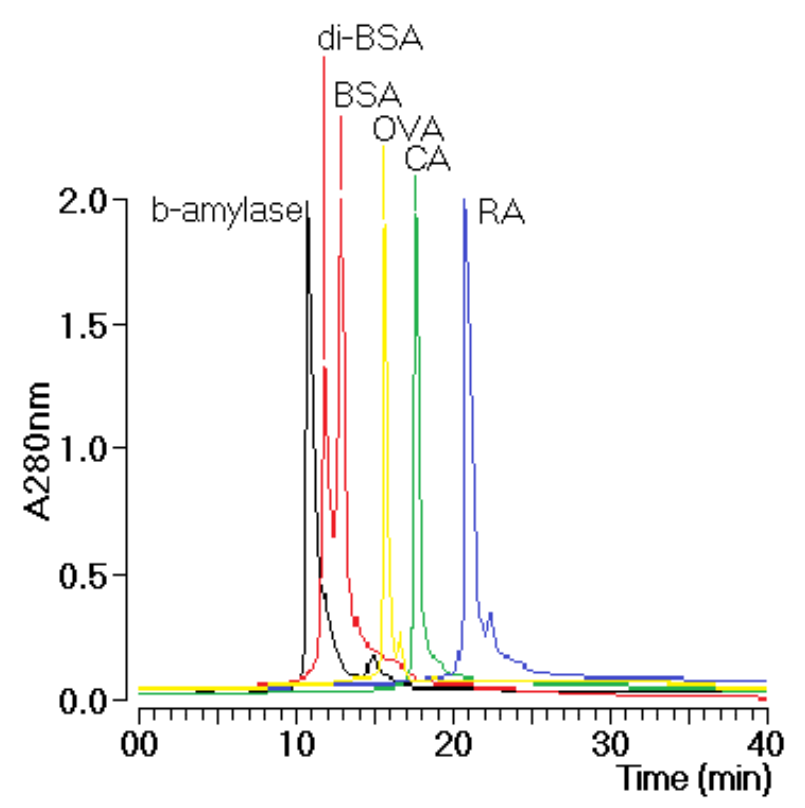


Figure 1. Cont.

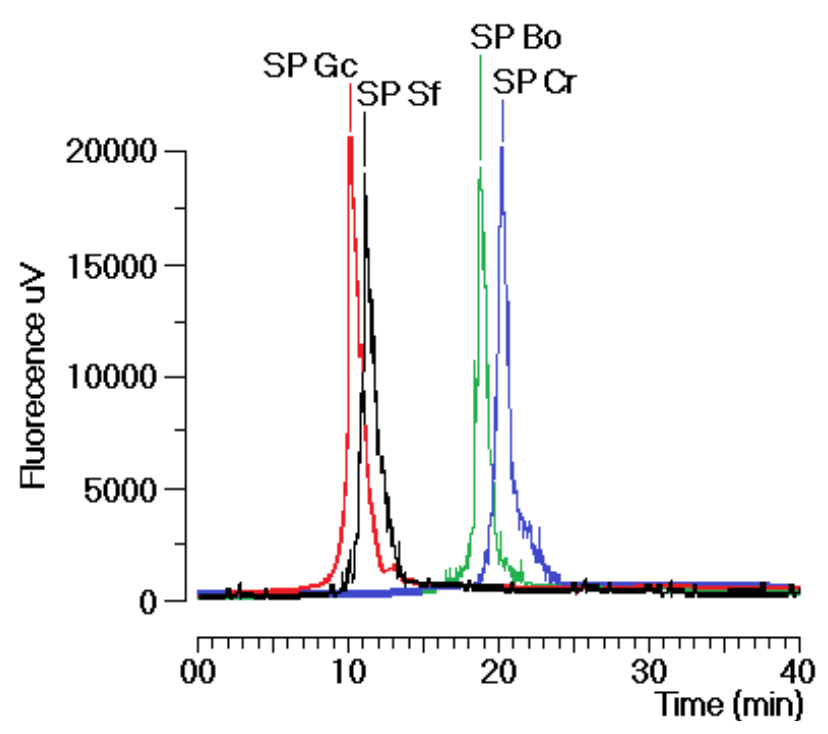

The SPCr significantly reduced the viability of the promastigotes of $L$. (L.) amazonensis in a dose-dependent manner and showed a low $\mathrm{EC}_{50}(34.5 \mu \mathrm{g} / \mathrm{mL})$ (Figure 2). Previous studies showed that the crude extracts of cold water Caulerpa sertularioides inhibited the growth rate of the promastigotes of Leishmania major and had an $\mathrm{EC}_{50}$ of $65 \mu \mathrm{g} / \mathrm{mL}$ [7] (Table 1). Moreover, the methanol extract of Caulerpa racemosa increased the leishmanicidal effect on the promastigotes of $L$. donovani and was able to eliminate $50 \%$ of the promastigotes with a dose of $22.6 \mu \mathrm{g} / \mathrm{mL}$ of extract [8]. Additionally, the SP C. racemosa used in this study showed moderate cytotoxic effects in the $\mathrm{J} 774$ macrophage cell line $\left(\mathrm{CC}_{50}=49.3 \mu \mathrm{g} / \mathrm{mL}\right)$ (Figure 3). These results suggest that SPCr may present potential leishmanicidal activity. These results can be extended by the studies of Süzgeç-Selçuk [8], which have shown that concentrations higher than $90 \mu \mathrm{g} / \mathrm{mL}$ of a crude extract of methanol were required to remove $50 \%$ of the L6 cell population. The chemical heterogeneity of this fraction found in the crude extract and the sensibility of cell lineage should result in a higher $\mathrm{EC}_{50}$ than those found in the present work.

SPBo also significantly reduced the viability of the promastigotes of $L$. (L.) amazonensis in a dose-dependent relation and showed a lower $\mathrm{EC}_{50}(58.8 \mu \mathrm{g} / \mathrm{mL})$ (Figure 2). Although these results demonstrated that the sulfated polysaccharides showed good activity against the growth of L. (L.) amazonensis, there are few studies showing other applications of algae of the genus Botryocladia. There are some studies with B. leptopoda. One of these studies showed that the crude extract and hexane fraction brought about a marked reduction in the peripheral microfilarial level in the rodent filarial parasites [9]. Moreover, studies with steroidal alkaloids from B. leptopoda showed moderate in vitro anti-leishmanial activity of approximately $60.81 \pm 0.41 \mu \mathrm{g} / \mathrm{mL}$ [10]. Recent studies by Sabina et al. [11] showed that ethanol extracts of algae, including B. leptopoda, also showed significant in vitro anti-leishmanial activity. The analysis of the results obtained from the in vitro treatment of $L$. (L.) amazonensis promastigotes with SPBo were significantly better than the in vitro anti-leishmanial activity from secondary metabolites because the molecular weights of the natural compounds are smaller than $1 \mathrm{kDa}$ and the sulfated polysaccharides of B. occidentalis had a molecular mass of $30 \mathrm{kDa}$. Studies conducted by Sabina et al. [11] identified that the flavone extracted from the red seaweed Osmundea pinnatifida showed inhibition of viability in tests with Leishmania. The SP 
from $B$. occidentalis had the second most potent cytotoxic effects on the $\mathrm{J} 774$ macrophage cell line $\left(\mathrm{CC}_{50}=27.3 \mu \mathrm{g} / \mathrm{mL}\right)($ Figure 3$)$ and the lowest selectivity index $(\mathrm{SI}=0.42)($ Table 1$)$.

Figure 2. Anti-promastigote effects of SP from the seaweeds Solieria filiformis (Sf), Botryocladia occidentalis (Bo), Caulerpa racemosa (Cr), and Gracilaria caudata (Gc) on L. (L.) amazonensis. ${ }^{*} p<0.05$ indicates significant anti-promastigote effects compared to untreated promastigote forms.

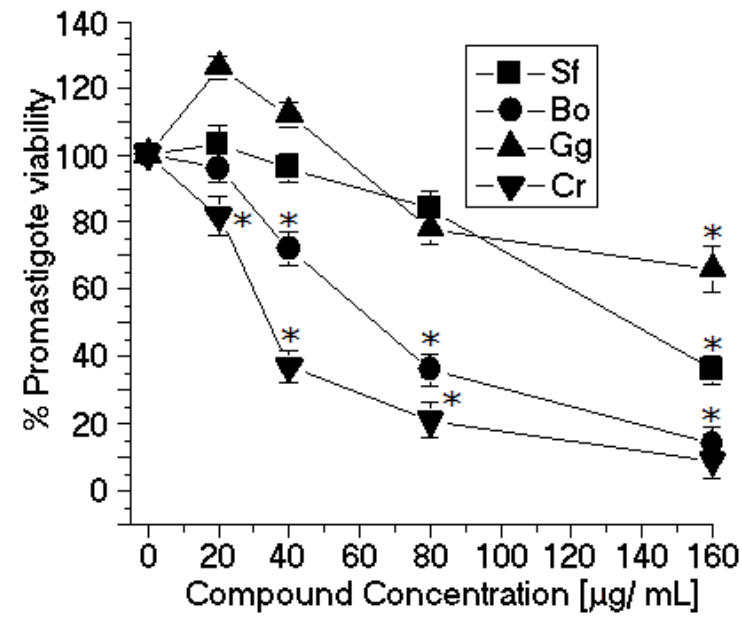

Table 1. Determination of the $\mathrm{EC}_{50}$ and $\mathrm{CC}_{50}$ values and selectivity indices of the purified sulfated polysaccharides in comparison with Amphotericin B.

\begin{tabular}{cccc}
\hline Algae species & EC50 $(\boldsymbol{\mu g} / \mathbf{m L})$ & CC50 $(\boldsymbol{\mu g} / \mathbf{m L})$ & Selectivity index \\
\hline C. racemosa & 34.5 & 49.3 & 1.42 \\
B. occidentalis & 63.7 & 27.3 & 0.42 \\
S. filiformis & 137.4 & 99.8 & 0.72 \\
G. caudate & No activity & 73.2 & Not determined \\
Amphotericin B & 0.05 & $\geq 90$ & - \\
\hline
\end{tabular}

Figure 3. Cytotoxic effects of SP from the seaweeds $\mathrm{Sf}, \mathrm{Bo}, \mathrm{Cr}$, and $\mathrm{Gc}$ on $\mathrm{J774}$ macrophages. ${ }^{*} p<0.05$ indicates significant cytotoxic effects compared to untreated J774 cells.

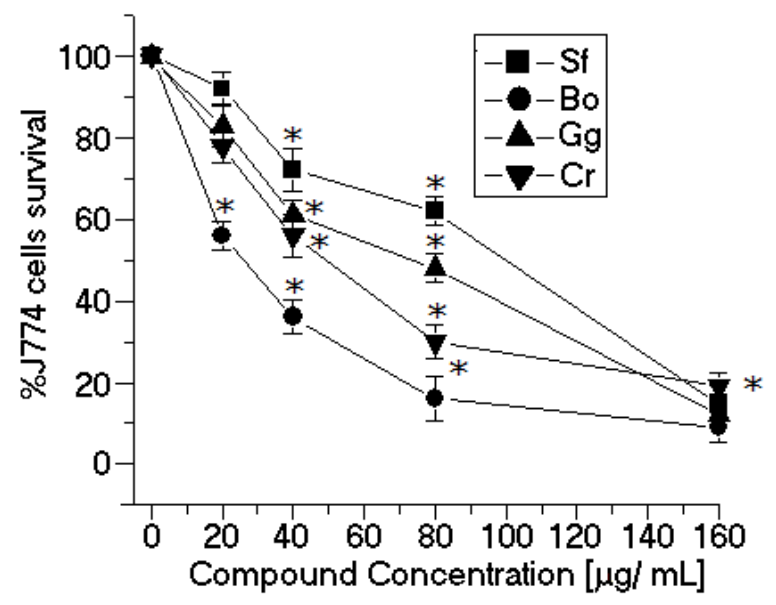


In contrast, the SP from Solieria filiformis presented the highest anti-leishmanial values $\left(\mathrm{EC}_{50}=137.4 \mu \mathrm{g} / \mathrm{mL}\right)$ (Figure 2$)$ and cytotoxic activities $\left(\mathrm{CC}_{50}=99.8 \mu \mathrm{g} / \mathrm{mL}\right)$ (Figure 3$)$. The selectivity index was $0.72 \mu \mathrm{g} / \mathrm{mL}$, thus suggesting that the cytotoxicity is responsible for killing the leishmania, rather than being a direct effect on the promastigote forms (Table 1). The SP from Gracilaria caudata algae showed no anti-leishmanial effect; however, a $\mathrm{CC}_{50}$ of $73.2 \mu \mathrm{g} / \mathrm{mL}$ was reached. Studies by Fouladvand et al. [7] investigated the $\mathrm{IC}_{50}$ values for the hot water extracts of Gracilaria corticata $\left(\mathrm{IC}_{50} \leq 38 \mu \mathrm{g} / \mathrm{mL}\right)$, Gracilaria salicornia $\left(\mathrm{IC}_{50} \leq 46 \mu \mathrm{g} / \mathrm{mL}\right)$ and Gracilaria salicornia $\left(\mathrm{IC}_{50}>105 \mu \mathrm{g} / \mathrm{mL}\right)$ and the cold water extract of Gracilaria corticata $\left(\mathrm{IC}_{50}>74 \mu \mathrm{g} / \mathrm{mL}\right)$. Studies on the anti-leishmanial effects of Mediterranean red algae showed that halogenated compounds from these algae have strong leishmanicidal activities [7].

The seaweed-derived SP tested in this study significantly inhibited the promastigote growth rate in vitro. Some of the observed $\mathrm{IC}_{50}$ values were comparable to those of other natural products, such as other organic small molecules isolated from algae sources. This article is the first report of the anti-leishmanial activity of algae SP. Our results also showed that none of the SP assayed here significantly modified the peritoneal macrophage viability (Figure 4). The difference between the cytotoxicity of the $\mathrm{J} 774$ macrophages and macrophages collected from the peritoneum is the resulting heterogeneity in the intracellular survival among the various macrophage-sensitive mutants, which may reflect the relative importance of the individual mutated genes in survival within macrophages [12]. The in vitro anti-leishmanial activity of sulfated polysaccharides depends on the molecular size of the sulfated polysaccharides. Our results show that the SP with high molecular weights showed the worst inhibition results. In the case of the sulfated polysaccharides of Botryocladia occidentalis and Caulerpa racemosa, the difference in molecular weight is small; therefore, the chemical composition of both sulfated polysaccharides can determine the best in vitro anti-leishmanial activity.

Figure 4. Cytotoxic effects of SP from the seaweeds Sf, Bo, Cr, and Gc on peritoneal macrophages. $* p<0.05$ indicates significant cytotoxic effects compared to untreated peritoneal macrophage.

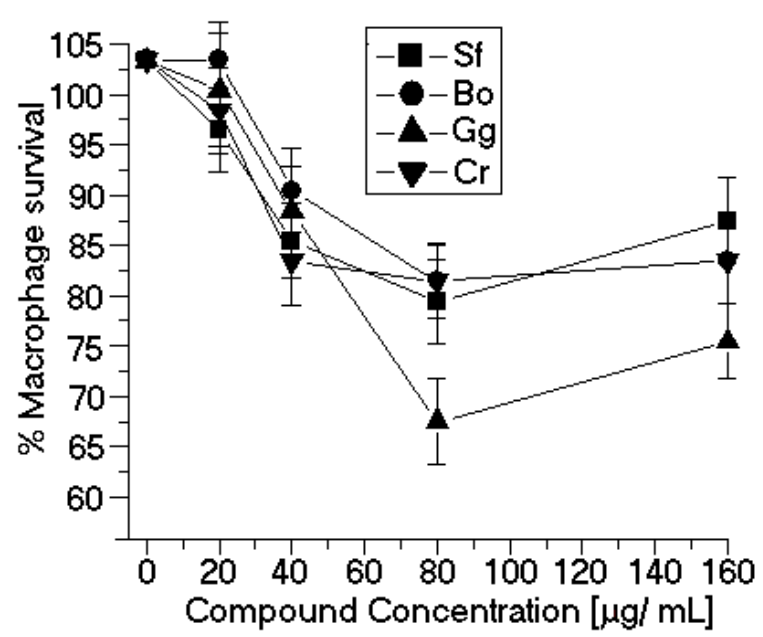




\section{Experimental Section}

\subsection{Specimen Collection}

Solieria filiformis (Sf), Botryocladia occidentalis (Bo), Caulerpa racemosa (Cr) and Gracilaria caudata $(\mathrm{Gc})$ were collected from the coast of Fortaleza, Brazil during the summer. After collection, all samples were washed thoroughly under tap water, packed in plastic bags, transported to the laboratory on dry ice, washed with Milli Q water, and stored at $-80{ }^{\circ} \mathrm{C}$ until the extracts were prepared. The fraction of SP from seaweed was supplied by Prof. Dr. Wladimir R. L. Farias (group of Department de Engenharia de Pesca/Biologia Molecular e Biologia Marinha, UFC, Fortaleza, Ceará, Brazil).

\subsection{Fractionation of the SP from Algae}

All of the dry seaweed $(5 \mathrm{~g})$ was triturated and hydrated in $250 \mathrm{~mL}$ of $0.1 \mathrm{M}$ sodium acetate, $5 \mathrm{mM}$ cysteine and $5 \mathrm{mM}$ EDTA, pH 5.0. Immediately afterward, $17 \mathrm{~mL}$ of crude papain solution $(30 \mathrm{mg} / \mathrm{mL})$ was added, and the mixture was incubated in a water bath at $60{ }^{\circ} \mathrm{C}$ for $24 \mathrm{~h}$. The material was then filtered and centrifuged $\left(14,000 \mathrm{rpm}, 30 \mathrm{~min}, 4^{\circ} \mathrm{C}\right)$. After this step, $16 \mathrm{~mL}$ of cetylpiridinium chloride (CPC) was added to provide a final concentration of $10 \%$. The solution was incubated at room temperature for $24 \mathrm{~h}$ to allow the polysaccharides to precipitate. The SPs were washed with $500 \mathrm{~mL}$ CPC, dissolved in $174 \mathrm{~mL}$ of $2 \mathrm{M} \mathrm{NaCl}$ :ethanol (100:15, v:v) in a water bath at $60{ }^{\circ} \mathrm{C}$, and precipitated again by the addition of $305 \mathrm{~mL}$ of absolute ethanol for $24 \mathrm{~h}$ at $4{ }^{\circ} \mathrm{C}$. The material was centrifuged again and washed successively with $500 \mathrm{~mL}$ of absolute ethanol and $300 \mathrm{~mL}$ of $80 \%$ ethanol. The SPs were dried in an oven at $60{ }^{\circ} \mathrm{C}$ for $24 \mathrm{~h}$ to obtain the SP-rich fraction. The crude extracts were purified on a DEAE-cellulose resin equilibrated with $0.1 \mathrm{M}$ sodium acetate, $5 \mathrm{mM}$ cysteine, and $5 \mathrm{mM}$ EDTA, $\mathrm{pH}$ 5.0. The polysaccharides adsorbed onto the ion exchange resin were eluted with $1.5 \mathrm{M} \mathrm{NaCl}$ using gel equilibration buffer. The quantification of SP was carried out through a metachromatic reaction using a spectrophotometer at $\lambda_{\max } 525 \mathrm{~nm}$. The high-performance liquid chromatography instrumentation was from Jasco (Jasco Analytical Instruments; 28600 Mary's Court Easton, MD 21601, USA): Model PU-2080 pump; Chronav system controller; Rheodyne injector equipped with a $20-\mu \mathrm{L}$ loop; FP-2020 fluorescence detector, MD-2015/2018 diode array arrangement detector and an ELC-2041 evaporative light scattering detector. The TSK G3000SWXL SEC column $(0.7 \times 300 \mathrm{~mm})$ was equilibrated with phosphate buffer $(0.05 \mathrm{M}, \mathrm{pH} 7.5)$ for $30 \mathrm{~min}$ at a flow rate of $1 \mathrm{~mL} / \mathrm{min}$ before sample addition. Aliquots of $200 \mu \mathrm{L}$ of sulfated polysaccharide were loaded on the column. The elution was performed at a flow rate of $1 \mathrm{~mL} / \mathrm{min}$ and was monitored by UV-Vis detection at $\lambda_{\max } 280 \mathrm{~nm}$. For this study, we used the protein markers blue dextran (BD, $2000 \mathrm{kDa}) ; \beta$-amylase $(\mathrm{BA}, 225 \mathrm{kDa})$; bovine serum albumin (BSA, Sigma, $66 \mathrm{kDa}$ ), which forms a natural dimer of $120 \mathrm{kDa}$, ovalbumin (OVA, $43 \mathrm{kDa}$ ); carbonic anhydrase $(\mathrm{CA}, 29 \mathrm{kDa})$; and ribonuclease $(\mathrm{RA}, 14 \mathrm{kDa})$ to estimate the molecular weight of the various SP. All samples were analyzed under the same buffer, flow rate and column chromatographic conditions. 


\subsection{Determination of Anti-Leishmanial Activity}

L. (L.) amazonensis (MHOM/BR/73/M2269 strain) parasite was classified on the basis of characteristic monoclonal antibodies and isoenzymes at the Evandro Chagas Institute, Belém, PA, Brazil. This strain was maintained in the footpad of BALB/c mice to keep their infectivity. The parasites were isolated, cultured, and maintained at $25{ }^{\circ} \mathrm{C}$ in RPMI 1640 medium supplemented with $10 \%$ heat-inactivated fetal bovine serum, $0.25 \mathrm{mM}$ HEPES, gentamicin $(10 \mu \mathrm{g} / \mathrm{mL})$, and penicillin (100 IU/mL) (R10 medium). The anti-leishmanial assays were performed following the protocol described by Passero et al. [13]. Briefly, promastigotes in the stationary phase of growth were washed three times with phosphate buffer solution (PBS) and suspended in RPMI 1640 at a concentration of 107 promastigote/mL in a 96-well plate. The SP were solubilized in PBS and sterilized by filtration through a $0.22 \mu \mathrm{m}$ membrane before being added to the culture. The SPs were individually added to the culture of $L$. (L.) amazonensis in a range of 20 to $160 \mu \mathrm{g} / \mathrm{mL}$. After $24 \mathrm{~h}$ of incubation at $25{ }^{\circ} \mathrm{C}$, the viability of the promastigote forms were analyzed through the conversion of 3-(4,5-dimethylthiazol)-2, 5-diphenyl tetrazolium bromide (MTT) to formazan. Briefly, the plates were washed three times while shaking at $3000 \mathrm{rpm}$ for $10 \mathrm{~min}$ at $4{ }^{\circ} \mathrm{C}$, and $40 \mu \mathrm{L}$ of R10 medium plus $10 \mu \mathrm{L}$ of MTT $(5 \mathrm{mg} / \mathrm{mL})$ were added to each well. After $4 \mathrm{~h}, 50 \mu \mathrm{L}$ of $10 \%$ sodium dodecyl sulfate was added to each well. The plates were further incubated for $18 \mathrm{~h}$. Next, the plates were read in an ELISA reader at $\lambda_{\max } 595 \mathrm{~nm}$, and the $50 \%$ effective concentration $\left(\mathrm{IC}_{50}\right)$ of each $\mathrm{SP}$ was calculated with the aid of Origin 5.0 statistical software (Microcal Software, Northampton, MA, USA). Each assay was conducted in triplicate. Amphotericin B was used as the standard drug.

\subsection{Macrophage Cytotoxicity}

The cytotoxicity of the SPs was assayed against the mouse macrophage cell line J774 and BALB/c-peritoneal macrophages [14] using a colorimetric reaction based on the MTT assay. Briefly, both cell populations were plated at $106 \mathrm{cell} / \mathrm{mL}$ in a $96-$ well plate. The SPs (at the concentrations described above) were incubated with the cells for $24 \mathrm{~h}$ at $35{ }^{\circ} \mathrm{C}$ and $5 \% \mathrm{CO}_{2}$. Following the incubation, the plates were washed three times with PBS, and MTT solution was added as described in the determination of anti-leishmanial activity section. The cytotoxic concentration $50 \%$ inhibitory concentration (cytotoxic concentration; $\mathrm{CC}_{50}$ ) of each SP was calculated with the aid of Origin 5.0 statistical software (Microcal Software, Northampton, MA, USA). Each assay was conducted in triplicate.

\subsection{Selectivity Index Determination}

To determine the selectivity index (SI), the ratio of the $\mathrm{CC}_{50}$ value of the cytotoxic activity to the $\mathrm{EC}_{50}$ value of the antiprotozoal activity was calculated. When the SI value is $>10$, that compound presents antiprotozoal activity that is higher rather than its cytotoxicity [15].

\subsection{Lethality Assays}

Each SP was separately injected into the tail vein of ten mice in serial doses diluted in $100 \mu \mathrm{L}$ saline $(0.3-40 \mu \mathrm{g} / 100 \mathrm{~g}$ of body weight). The survival times of the animals were recorded for $24 \mathrm{~h}$. 


\subsection{Statistical Analysis}

The results are expressed as the means \pm standard deviation. The data were analyzed using Student's $t$ test. The level of significance was set at $p<0.05$.

\section{Conclusions}

Research with sulfated polysaccharides is one approach for the discovery and development of new drugs that could be used as an alternative to heparin. In the introduction, we presented a brief review of how the heparin-binding proteins (HBPS) that are present on the surface of Leishmania spp. may play important roles in the life cycle of parasites and in defining the success of parasite attachment to and invasion of tissues of the mammalian and invertebrate hosts. The relevance of this work is based on the fact that anti-leishmania therapy is based on pentavalent antimony compounds. The toxicity and persistent side effects of these agents are severe, even after modification of the dose level and the duration of treatment [16]. Our results show that the sulfated polysaccharides of algae can be an alternative to the use of heparin in the treatment of leishmaniasis, as these two compounds have similar molecular structures. In addition, the sulfated polysaccharides of algae showed a higher efficiency against the development of leishmaniasis than alkaloids, terpenoids and other natural products isolated from seaweed.

\section{Acknowledgments}

We thank the Research Foundation of the State of São Paulo (FAPESP) and the National Research Council (Edital MCT/CNPq/CT-Petro) for financial support.

\section{References}

1. Azevedo-Pereira, R.L.; Pereira, M.C.; Oliveira-Junior, F.O.; Brazil, R.P.; Cortes, L.M.; Santos, A.L.; Toma, L.; Alves, C.R. Heparin binding proteins from Leishmania (V.) brasiliensis promastigotes. Vet. Parasitol. 2007, 145, 234-239.

2. De Castro Côrtes, L.M.; de Souza Pereira, M.C.; da Silva, F.S.; Pereira, B.A.; de Oliveira Junior, F.O.; de Araújo Soares, R.O.; Brazil, R.P.; Toma, L.; Vicente, C.M.; Nader, H.B.; et al. Participation of heparin binding proteins from the surface of Leishmania (Viannia) braziliensis promastigotes in the adhesion of parasites to Lutzomyia longipalpis cells (Lulo) in vitro. Parasit. Vectors 2012, 5 , doi:10.1186/1756-3305-5-142.

3. De Castro Côrtes, L.M.; de Souza Pereira, M.C.; de Oliveira, F.O., Jr.; Corte-Real, S.; da Silva, F.S.; Pereira, B.A.; de Fátima Madeira, M.; de Moraes, M.T.; Brazil, R.P.; Alves, C.R. Leishmania (Viannia) braziliensis: Insights on subcellular distribution and biochemical properties of heparin-binding proteins. Parasitology 2012, 139, 200-207.

4. Rodrigues, J.A.G.; Farias, W.R.L. Avaliação comparativa dos polissacarídeos sulfatados extraídos de rodofíceas Halymenia spp.: Ferramenta taxonômica para algas? Rev. Bras. Eng. Pesca 2009, 4, 7-20. 
5. Mayer, A.M.; Rodríguez, A.D.; Berlinck, R.G.; Fusetani, N. Marine pharmacology in 2007-8: Marine compounds with antibacterial, anticoagulant, antifungal, anti-inflammatory, antimalarial, antiprotozoal, antituberculosis, and antiviral activities; Affecting the immune and nervous system, and other miscellaneous mechanisms of action. Comput. Biochem. Physiol. C Toxicol. Pharmacol. 2011, 153, 191-222.

6. Vonthron-Sénécheau, C.; Kaiser, M.; Devambez, I.; Vastel, A.; Mussio, I.; Rusig, A.M. Antiprotozoal activities of organic extracts from French marine seaweeds. Mar. Drugs 2011, 9 , 922-933.

7. Fouladvand, M.; Barazesh, A.; Farokhzad, F.; Malekizadeh, H.; Sartavi, K. Evaluation of in vitro anti-Leishmanial activity of some brown, green and red algae from the Persian Gulf. Eur. Rev. Med. Pharmacol. Sci. 2011, 15, 597-600.

8. Süzgeç-Selçuk, S.; Meriçli, A.H.; Güven, K.C.; Kaiser, M.; Casey, R.; Hingley-Wilson, S.; Lalvani, A.; Tasdemir, D. Evaluation of Turkish seaweeds for antiprotozoal, antimycobacterial and cytotoxic activities. Phytother. Res. 2011, 25, 778-783.

9. Lakshmi, V.; Kumar, R.; Gupta, P.; Varshney, V.; Srivastava, M.N.; Dikshit, M.; Murthy, P.K.; Misra-Bhattacharya, S. The antifilarial activity of a marine red alga, Botryocladia leptopoda, against experimental infections with animal and human filariae. Parasitol. Res. 2004, 93, 468-474.

10. Choudhary, M.I. Discovery of leishmanicidal agents from medicinal plants. Pure Appl. Chem. 2008, 80, 1783-1790.

11. Sabina, H.; Aliya, R. Bioactive assessment of selected marine red algae against Leishmania major and chemical constituents of Osmundea pinnatifida. Pak. J. Bot. 2011, 43, 3053-3056.

12. Buchmeier, N.A.; Heffron, F. Intracellular survival of wild-type Salmonella typhimurium and macrophage-sensitive mutants in diverse populations of macrophages. Infect. Immun. 1989, 57, $1-7$.

13. Passero, L.F.; Tomokane, T.Y.; Corbett, C.E.; Laurenti, M.D.; Toyama, M.H. Comparative studies of the anti-leishmanial activity of three Crotalus durissus ssp. venoms. Parasitol. Res. 2007, 101, 1365-1371.

14. Valentin, E.; Lambeau, G. Increasing molecular diversity of secreted phospholipases A(2) and their receptors and binding proteins. Biochim. Biophys. Acta 2000, 1488, 59-70.

15. Lambeau, G.; Gelb, M.H. Biochemistry and physiology of mammalian secreted phospholipases A2. Annu. Rev. Biochem. 2008, 77, 495-520.

16. Fagundes, F.H.R.; Ricardo, A.; dos Santos, M.L.; Diz Filho, E.B.S.; Oliveira, S.C.B.; Toyama, D.O.; Toyama, M.H. A catalytically inactive Lys49 PLA2 isoform from Bothrops jararacussu venom that stimulates insulin secretion in pancreatic beta cells. Protein Pept. Lett. 2011, 18, 1133-1139.

(C) 2013 by the authors; licensee MDPI, Basel, Switzerland. This article is an open access article distributed under the terms and conditions of the Creative Commons Attribution license (http://creativecommons.org/licenses/by/3.0/). 